\title{
Unilateral Nevoid Telenjiektazi: Olgu Sunumu
}

\author{
Unilateral Nevoid Telangiectasis: Case Report
}

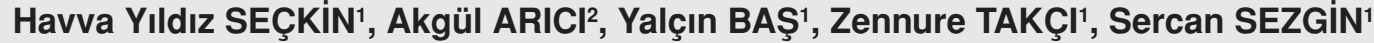

1 Gaziosmanpaşa Üniversitesi Tıp Fakültesi Deri ve Zührevi Hastalıklar Anabilimdalı, Tokat 2 Gaziosmanpaşa Üniversitesi Tıp Fakültesi Patoloji Anabilimdalı, Tokat

\section{ÖZET}

Unilateral nevoid telenjiyektazi (UNT) tek taraflı dermatomal yerleşim gösteren yüzeyel telenjiektazik yamalarla karakterize, nadir görülen bir cilt hastalığıdır. Konjenital veya edinsel olabilir. Konjenital formlar erkeklerde ve edinsel formlar da kadınlarda daha sıktır. Etyopatolojisi halen tam olarak bilinmemesine rağmen edinsel formun hiperöstrojenizm ile ilişkili olduğu ileri sürülmektedir. Burada edinsel UNT tanısı konulan bir erkek hasta sunulmaktadır.

Anahtar Kelimeler: Unilateral nevoid telenjiyektazi, telenjiyektazi

\section{ABSTRACT}

Unilateral nevoid telangiectasia (UNT) is a rare cutaneous disease, which is characterized by unilateral, dermatomal superficial telangiectatic patchs. UNT can be congenital or acquired. Congenital forms are more common in men and acquired forms are more common in women. Although its etiopathologic mechanism is still not known exactly, acquired form is suggested to be related with hyperestrogenism. Here we present a male patient with diagnosis of acquired UNT.

Key words: Unilateral nevoid telangiectasia, telangiectasia
Corresponding Author: Havva Yıldız Seçkin

Adress: Gaziosmanpaşa Üniversitesi Tıp Fakültesi Deri ve Zührevi Hastalıklar Anabilimdalı, Tokat

E-mail: havvayildiz1982@mynet.com
Başvuru Tarihi/Received: 16-06-2015 Kabul Tarihi/Accepted: 21-06-2015 


\section{Giriş}

Unilateral nevoid telenjiyektazi (UNT) konjenital veya akiz olabilen yüzeyel dermal telenjiyektazilerle karakterize, tek tarafı dermatomal yerleşimli, nadir görülen bir deri hastalığıdır. Trigeminal sinir ile üçüncü ve dördüncü servikal sinirlerin dermatomal alanları en sık tutulan alanlardır (1). Etyopatolojisi tam olarak anlaşılamamıştır. Ancak edinsel formunda kanda östrojen seviyelerinin yüksekliği ve/veya tutulan deride östrojen ve progesteron reseptörlerinin artışının gösterilmesi hormonal faktörlerin bu hastalık etyolojisinde rolü olduğunu düşündürmektedir (2).

UNT'nin gebelik, puberte, oral kontraseptif kullanımı, kronik karaciğer hastalığı, hepatit B ve C infeksiyonu, hipertiroidi gibi kanda östrojen artışının görüldüğü hastalıklarla birlikteliği bildirilmiştir (3). Ancak hiperöstrojenizm olmayan sağlıklı bireylerde de görülebildiği bilinmektedir. Bu makalede kilinik ve histopatolojik olarak edinsel UNT tanısı konulan bir erkek hasta sunulmakta ve litaretür bilgileri tartışımaktadır.

\section{Olgu Sunumu}

On dört yaşında erkek hasta yaklaşık 10 yıldır yüzünde tek taraflı var olan kızarık leke şikayeti ile polikliniğimize başvurdu. Hastanın dermatolojik muayenesinde yüzünün sol yarısında alın, burun dorsumu ve sol göz çevresinde eritemli zemin üzerinde yerleşmiş düzensiz sınırlı basmakla solmayan, telenjiektazik plaklar görüldü (resim 1). Ek başka bir hastalığı veya ilaç kullanım öyküsü yoktu. Lekeleri stabil karakterdeydi. Aile öyküsü yoktu. Hastadan yapılan tam kan sayımı, serum biyokimyası, tiroid fonksiyonları östrojen, progesteron düzeyleri ve hepatit serolojisi normal sınırlardaydı. Telenjiektazik plaklardan alınan punch biyopsi örneğinde papiller dermiste küçük çaplı damarlarda artış, bazı damarlarda ektazik görünüm, perivasküler hafif lenfositik infiltrasyon görüldü (şekil 1). Klinik ve histopatolojik bulgular sonucunda unilateral UNT tanısı konuldu.

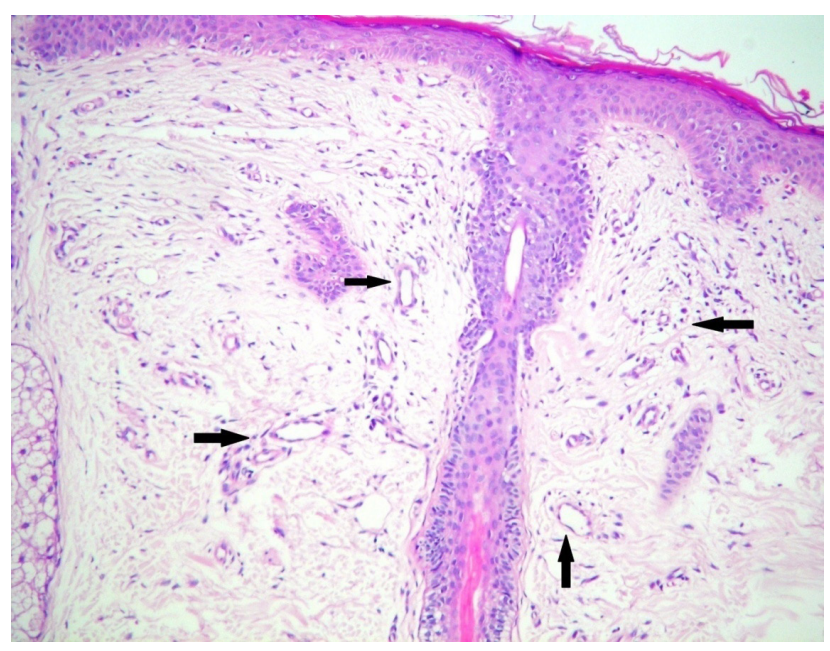

Şekil 1: Papiller dermiste küçük çaplı damarlarda artış, bazı damarlarda ektazik görünüm (oklar), perivasküler hafif lenfositik infiltrasyon (Hematoksilin eozin $\mathrm{x}$ 100).

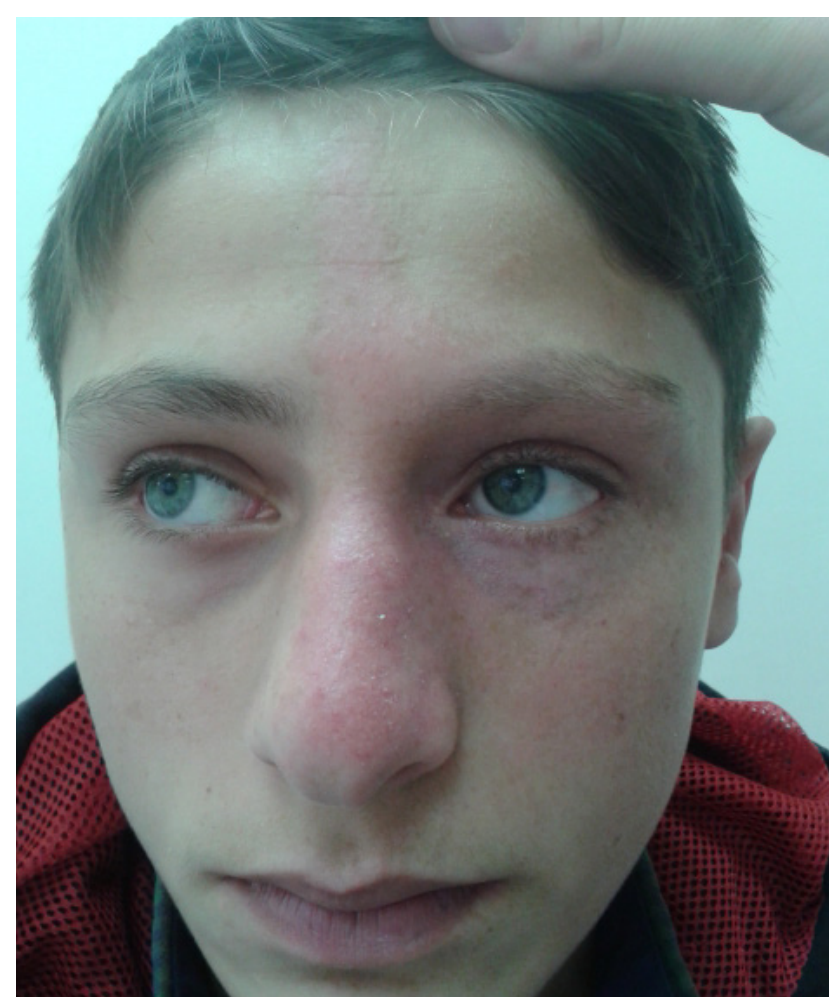

Resim 1: Yüzünün sol yarısında alın, burun dorsumu ve sol göz çevresinde eritemli zemin üzerinde yerleşmiş düzensiz sınırlı basmakla solmayan, telenjiektazik plaklar. 


\section{Tartş̧ma}

UNT primer telenjiektaziler arasında yer alan, genellikle edinsel olarak görülen nadir olarak bildirilen bir cilt hastalığıdır. Nadir olarak bildirilmesine rağmen gerçek sıklıklığının daha fazla olduğu tahmin edilmektedir. Klinik olarak tek taraflı, lineer veya Blaschkoid dağılım gösteren, dermatomal yerleşimli çok sayıda yüzeyel dermal telenjiyektazilerle karakterizedir. Sıklıkla vücudun sol tarafında trigeminal, servikal ve üst torakal dermatom alanlarına görülmekle beraber daha nadir olarak sağ tarafta veya lumbar ve sakral dermatomlarda yerleşen vakalar bildirilmiştir. Oral ve genital mukoza tutulumu eşlik edebilir. Kadınlarda iki kat daha sıktır. Edinsel form kadınlarda, konjenital form erkeklerde daha sık görülmektedir. Konjenital form yenidoğan döneminde veya daha sonra ortaya çıkar $(4,5)$.

UNT etyopatolojisi halen tam olarak bilinmemektedir. Edinsel formunun gebelik, ergenlik, karaciğer hastalıkları, kronik alkolizm ve hormon tedavisi gibi östrojen seviyesinin arttığı durumlarda daha çok görüldüğü ileri sürülmektedir. Tutulan deride östrojen ve progesteron reseptörlerinin arttığını gösteren olgu bildirileri vardır.
Östrojenin anjiojenik bir faktörü uyararak telenjiektaziye yol açabileceği düşünülmektedir (6). Ayrıca litaretürde hepatit $B$ ve $C$ enfeksiyonu, kronik alkolizm, portal hipertansiyon, metastatik karsinoid sendrom ve hipertiroidizm gibi hastalıklarla birlikteliği bildirilmiştir $(3,7)$.

UNT histopatolojik değerlendirmesinde dermiste çok sayıda genişlemiş telenjiyektatik kan damarları ve etrafinda minimal inflamatuvar infiltrat tipik bulgularıdır. Ayırıcı tanıda kapiller hemanjiyom, anjiom serpijinöz, nevüs flammeus gibi diğer vasküler lezyonlar düşünülebilir. UNT kalıcıdır ancak çok nadiren kendiliğinden gerileyebilir (8). Tedavi kozmetik amaçlıdır ve kamuflaj ve vasküler lazer tedavisi önerilebilir.

Olgumuzda lezyonlar 4 yaşında başlamış olup lezyonlar sol tarafta ve trigeminal sinirin oftalmik dalının olduğu alanlarda yerleşim gösteriyordu. Eşlik eden herhangi bir hastalık yoktu. Ayrıca ilaç ve kozmetik kullanım öyküsü bulunmuyordu.

Sonuç olarak UNT etyopatolojisi halen tam olarak anlaşılmamıştır. Tamamen sağlıklı bireylerde görülebileceği gibi başka hastalıklarla ilişkili olabileceği unutulmamalıdır. Etyopatolojisinin aydınlatılması için geniş gruplarda seri çalışmalarına ihtiyaç vardır.

\section{KAYNAKLAR}

1. Tok J, Berberian BJ, Sulica VI: Unilateral nevoid telengiectasia syndrome. Cutis 1994;53:53-54.

2. Wilkin JK: Unilateral nevoid telangiectasia: three new cases and the role of estrogen. Arch Dermatol 1977;113: 486-488.

3. Turan H, Gönen I, Albayrak H, Aliağaoğlu C. Acquired unilateral nevoid telangiectasia syndrome accompanied by chronic hepatitis B virus infection. Acta Dermatovenerol Croat. 2013 Aug;21(2):133-4.

4. Guedes R, Leite L. Unilateral nevoid telangiectasia: a rare disease? Indian J Dermatol. 2012 Mar;57(2):13840.

5. See comment in PubMed Commons belowJordão JM,
Haendchen LC, Berestinas TC, Faucz LR. Acquired unilateral nevoid telangiectasia in a healthy men. An Bras Dermatol. 2010 Nov-Dec;85(6):912-4.

6. Karabudak O, Dogan B, Taskapan O, Harmanyeri Y. Acquired unilateral nevoid telangiectasia syndrome. J Dermatol. 2006 Nov;33(11):825-6.

7. Beacham CE, Kurgansky D: Unilateral naevoid telangiectasia syndrome associated with metastatic carcinoid tumor. Br J Dermatol 1991;124: 86-88.

8. Wenson SF, Jan F, Sepehr A. Unilateral nevoid telangiectasia syndrome: A case report and review of the literature. Dermatol Online J 2011;17: 2. 